International Journal of Social Sciences and Humanities
Available online at http://sciencescholar.us/journal/index.php/ijssh
Vol. 2 No. 2, August 2018, pages: 77 86
e-ISSN: 2550-7001, p-ISSN: 2550-701X
http://dx.doi.org/10.29332/ijssh.v2n2.131

\title{
Culture of Tri Hita Karana on Ease of Use Perception and Use of Accounting Information System
}

\author{
CrossMark \\ I Gusti Ayu Agung Omika Dewi ${ }^{\text {a }}$ I Gusti Ayu Agung Pradnya Dewi ${ }^{\text {b }}$, Ketut Tanti Kustina c, \\ Gine Das Prena d, \\ Article history: Received 9 August 2017, Accepted in revised form 1 March 2018, Approved 28 May 2018, \\ Available online 8 June 2018
}

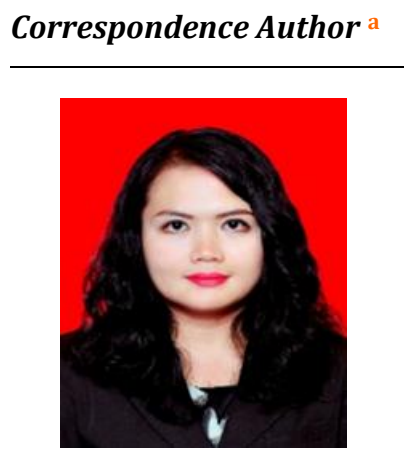

Keywords

Badung regency;

Philosophy;

Tri hita karana;

Using ease perception;

Accounting information

System;

\begin{abstract}
The problem raised in the present research was the implementation of a culture of Tri Hita Karana. It was one of the philosophy that underlies all aspects of Balinese life in their interaction including on organizational life. The study was intended to examine and analyze the effect of the culture of Tri Hita Karana on the use of Accounting Information System. As well, the indirect effect of the culture of Tri Hita Karana implementation on the use of Accounting Information System moderated perceived ease of use. The research object was Small and Medium Enterprises in Badung Regency. Data collection techniques were used in the study included a questionnaire. The sampling techniques were used in stratified random sampling. Data analysis technique in this research was analyzed through moderated regression analysis. The hypothesis test results showed that 1) Culture of Tri Hita Karana has a positive effect on the use of Accounting Information System. 2) Perception of use ease can strengthen cultural of Tri Hita Karana relationships and Use of Accounting Information System.
\end{abstract}

e-ISSN : 2550-7001, p-ISSN : 2550-701X ${ }^{\odot}$ Copyright 2018. The Author. SS Journals Published by Universidad Técnica de Manabí. This is an open-access article under the CC BY-SA 4.0 license (https://creativecommons.org/licenses/by-sa/4.0/) All rights reserved.

\section{Contents}

Abstract

1. Introduction

2. Research Methods 77

3. Results and Analysis

3. Results and Analysis

a University of National Education (UNDIKNAS) Denpasar, Indonesia

b University of National Education (UNDIKNAS) Denpasar, Indonesia

c University of National Education (UNDIKNAS) Denpasar, Indonesia

d University of National Education (UNDIKNAS) Denpasar, Indonesia 


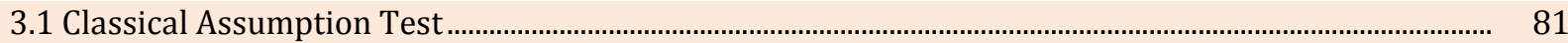

3.2 Regression Analysis with Moderating Variable ...............................................................................................

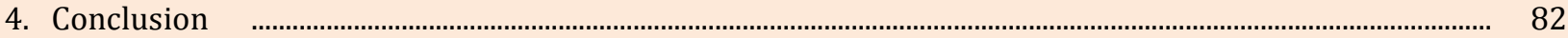

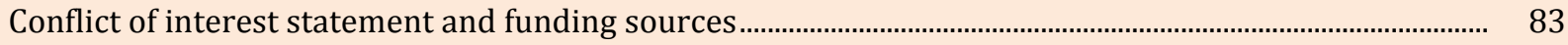

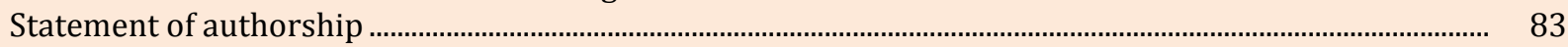

Acknowledgements

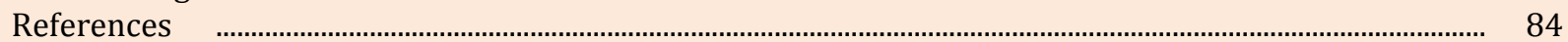

Biography of Authors

\section{Introduction}

Small and Medium Enterprises (SMEs) is one of the strategic sectors that can drive the Indonesian economic development. According to Manurung (2006) stated that SMEs were one of savior in Indonesian economy when experiences a crisis in 1997. At that time, there were many Termination of Employment (PHK) in the industry and large companies due to the prolonged crisis impact. SMEs provide a new employment alternative that can reduce the unemployment rate in Indonesia.

The competition in the business world included SMEs is getting tighter with the existence of Asian Economic Community (MEA). Technology is one of the keys for SMEs able to compete in the current era of globalization and free trading. Accounting Information System (AIS) can help SMEs to compete in the digital era, where in addition to providing a recording system, AIS is able to process financial information to produce credible and competent data for further analysis. In addition to keeping up with the times to remain competitive, the use of AIS will help SMEs to monitor their performance. Manual cash records will only be confusing and will not be able to show SMEs cash flow conditions. If the financial statements are made with clear standards and procedures, it will be formed a benchmark for SMEs to determine their performance. SMEs will also get easier a venture capital loan if they attach a financial report whose credibility is not in doubt.

To maximally and effectively function, the management and use of AIS should also be considered. Burch et al. (1991) stated that AIS is always related to the human role in an organization. Human factors also play an important role in the AIS application (Halim, 1994: 259). Based on the Technology Acceptance Model (TAM), the use of information systems is closely related to user behavior (Hartono, 2007: 17). One of the factors that can influence the individual behavior within an organization is culture (Pragatha, 1995). Thus, culture is also able to influence the use of information systems within the organization. Rahayu (2012) stated that organizational culture affects the implementation of AIS.

Tri Hita Karana (THK) is one of a society local culture in Bali. THK philosophy is well known in the Balinese lifestyle that is a Hindu community tradition in Bali. THK is the philosophy that underlies Balinese people in fostering harmonious relationships to the God with fellow human beings as well as with the environment. THK is local wisdom that becomes the benchmark for individuals in Bali to carry out their activities in the organization management, including in the use of AIS.

The present study included the variable of using ease perception that moderates the relationship between the culture of THK with the use of AIS. It is one component of TAM that emphasizes on consumer acceptance of information systems used. If SMEs in Bali apply culture of THK to the use of AIS, a balance due to the implementation of a culture of THK will be more effective in using AIS, especially, if users feel comfortable when using AIS.

\section{Research Issues}

Based on the above description, the issues are discussed in the present research are (1) whether the culture of THK influences the use of AIS; (2) whether the use ease perception is able to moderate the relationship between the culture of THK and the use of AIS. 
Research aims

Based on the issues that have been above described, the research aims is (1) to determine the influence of the culture of THK on the use of AIS; (2) to know the use ease perception is able to moderate the relationship between the culture of THK and the use of AIS.

\section{Literature Review}

Technology Acceptance Model

Technology Acceptance Model (TAM) was first developed by Davis (1989) is Information System (SI) model developed to predict the adoption and use of SI. TAM is a widely adopted application of Theory of Reasoned Action (TRA). TAM adds two main constructs to TRA model, namely: usability and ease of use in addition to other constructs, i.e., interest in use and usage (Davis, 1989). The model purpose is to be able to explain the main factors of the behavior of information technology users on the acceptance and the usage of information technology itself.

\section{Culture of Tri Hita Karana}

THK philosophy is well known in the Balinese lifestyle, i.e., Hindu community tradition in Bali. THK principle is a philosophy taught in Bhagavadgita, which teaches the three main subjects to human achieving ultimate happiness. Dharma or truth of God and human nature enhances the heart's conviction of the truth of God, and how to act in God's righteousness (Palguna 2007). THK is defined as the three welfare causes that come from the harmony of the relationship between: human and God (parahyangan), human and natural environment (palemahan), and human and human (pawongan) (Dalem, 2007).

\section{Accounting Information System}

Accounting Information System (AIS) is defined by Bodnar and Hopwood (2010: 1), "an Accounting Information System (AIS) is a collection of resources, such as people and equipment, designed to transform financial and other data into information." AIS performs these transformations to determine their basic manual system or through computerization. According to Mulyadi (2001: 3), AIS is a form organization, note, and report is coordinated in such a way as to provide financial information needed by management to facilitate the company management. Whereas, according to Romney and Steinbart (2012: 30), AIS is a system that collects, records, stores, and processes accounting data and other data to generate information for decision-makers.

\section{Research Methods}

\section{Population and Sample}

The research population in the present research is all SMEs in Badung regency. There are 1068 SMEs. The samples number taken was calculated using slovin pattern. It is obtained 305 SMEs samples. The method of collecting the sample is used in the research is proportionate stratified random sampling. This sampling technique is used due to the population has members or elements that are not homogeneous and stratified proportionally (Sugiyono, 2012: 93).

Dewi, I., Dewi, I., Kustina, K., \& Prena, G. (2018). Culture of tri hita karana on ease of use perception and use of accounting information system. International Journal Of Social Sciences And Humanities (IJSSH), 2(2), 77-86. doi:10.29332/ijssh.v2n2.131 


\section{Research Model}

The research model used in this study is in the following figure:

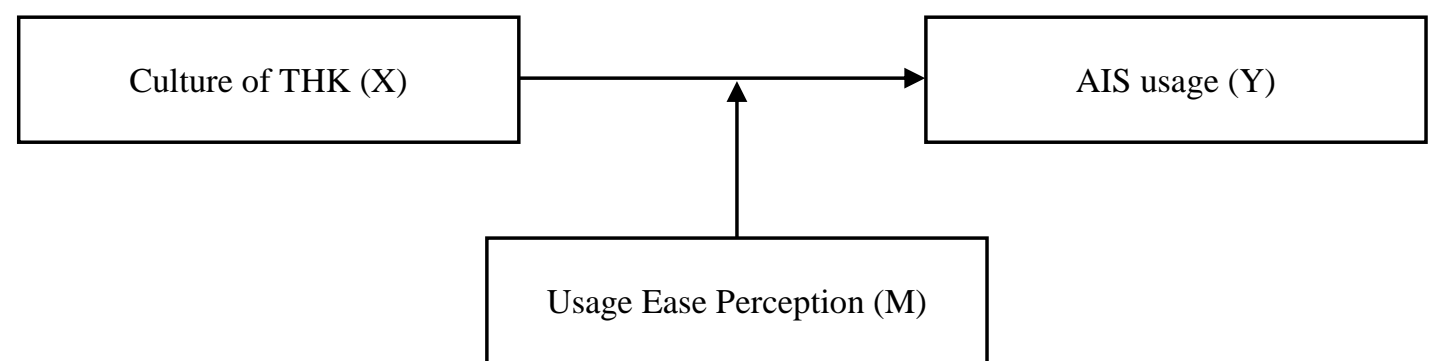

Figure 1. Research Model

\section{Data Analysis Techniques}

a) Classical assumption test

A good linear regression test is free of normality issues, multicollinearity, heteroscedasticity, and autocorrelation. However, in this research, autocorrelation test is not conducted due to the data used is not time series data, and multicollinearity test is not conducted due to this research uses only one independent variable.

1. Normality test

Ghozali (2009) stated that the normality test is performed to test whether the residue of the regression equation is normally distributed or not. The method used is to use Kolmogorov-Smirnov statistics. Data is stated to be normally distributed when sig > alpha.

2. Heteroscedasticity test

Ghozali (2009) stated that heteroscedasticity test is conducted to determine whether or not variation inequality. Glejser model is implemented for testing. This model is conducted by regressing the absolute value, i.e. with an independent variable. If there is no absolute value, i.e. an independent variable has a significant effect on the dependent variable, then there is no heteroscedasticity.

b) Moderated Regression Analysis

The technique of analyzing the data is applied Moderated Regression Analysis (MRA), wherein the previously used data have passed the classical assumption test (normality and heteroscedasticity). This analytical technique is used to test the effect of moderation variables on the relationship of independent variables and bound by using interaction test. The data analysis result will get the moderation regression equation as follows:

$\mathrm{Y}=\alpha+\beta 1 \mathrm{X} 1+\beta 2 \mathrm{X} 1 \mathrm{X} 2+\mathrm{e}$

Description:

$\begin{array}{ll}\mathrm{Y} & =\text { AIS usage } \\ \alpha & =\text { Constants } \\ \mathrm{X} 1 & =\text { Culture of THK } \\ \mathrm{X} 2 & =\text { Usage ease perception } \\ \mathrm{e} & =\text { Error term } \\ \beta 1, \beta 2 & =\text { Regression coefficient }\end{array}$

Hypotheses Development

a) Effect of culture of THK on AIS usage 
Burch et al. (1991) stated that AIS is always related to the human role in an organization. The human factors are also a very important role in AIS application (Halim, 1994: 259). Based on TAM, the use of information systems is closely related to user behavior (Hartono, 2007: 17). One of the factors that can influence the individual behavior within an organization is culture (Pragatha, 1995). Thus, culture is also able to influence the use of information systems within an organization. Rahayu (2012) stated that organizational culture affects AIS implementation. Tunnel IV (2013) stated that National Culture can influence the use and AIS implementation. Suardikha (2011) and Suardikha (2013) found that culture of THK affects AIS usage. THK is local wisdom that becomes a benchmark for individuals in Bali to carry out their activities within an organization, included AIS usage. Based on the description, it can be formulated hypothesis as follows:

H1: Culture of THK has a positive effect on AIS usage

b) Moderation of ease of use perception towards to relationship between culture of THK and AIS usage

Davis (1989) stated that ease of use technology is defined as a measure in which the individual believes that the technology system can be easily understood and used, wherein a system is declared qualified. The system will be designed, to meet user satisfaction through ease of use system. Noviandini (2012) and Gunawan (2014) found that perceived ease of use had a positive effect on the use information systems. If SMEs in Bali apply culture of THK to use of AIS, the balance generated by the implementation culture of THK will be more effective in using AIS, especially, if the user perceived ease when using AIS. Based on the description, it can be formulated hypothesis as follows:

$\mathrm{H} 2$ : Ease of use perception strengthens the relationship between culture of THK and the use of AIS

\section{Results and Analysis}

\subsection{Classical Assumption Test}

Table 1

Classical Assumption Test Results

\begin{tabular}{ccc}
\hline \multirow{2}{*}{ Variable } & \multicolumn{2}{c}{ Classical Assumption Test } \\
\cline { 2 - 3 } & Normality & $\begin{array}{c}\text { Heteroscedasticity } \\
\text { Significance }\end{array}$ \\
\hline X1 2 Tailed & & 0,134 \\
X2 & 0,461 & 0,175 \\
X1X2 & & 0,109 \\
\hline
\end{tabular}

Source: Data Processed (2017)

Based on the above table, it can be concluded that the regression equation model is in this study used passed a classical assumption test. Wherein, the significance value on the normality test is $0.461(0.461>0.05)$. It means that a regression model is normally distributed. A regression model is also free from heteroscedasticity problems. Wherein, an independent and moderation variables have a greater significance than $\alpha(0.05)$.

Dewi, I., Dewi, I., Kustina, K., \& Prena, G. (2018). Culture of tri hita karana on ease of use perception and use of accounting information system. International Journal Of Social Sciences And Humanities (IJSSH), 2(2), 77-86. doi:10.29332/ijssh.v2n2.131 
3.2 Regression Analysis with Moderating Variable

Table 2

Regression Analysis with Moderating Variable

\begin{tabular}{|c|c|c|c|c|c|c|}
\hline \multirow{2}{*}{\multicolumn{2}{|c|}{ Model }} & \multicolumn{2}{|c|}{$\begin{array}{l}\text { Unstandardized } \\
\text { Coefficients }\end{array}$} & \multirow{2}{*}{$\begin{array}{c}\text { Standardized } \\
\text { Beta }\end{array}$} & \multirow[b]{2}{*}{$\mathrm{t}$} & \multirow[b]{2}{*}{ Sig. } \\
\hline & & $\mathrm{B}$ & Std. Error & & & \\
\hline \multirow[t]{6}{*}{1} & (Constant) & 11,813 & 4,414 & & 2,676 & 0,008 \\
\hline & $\mathrm{X}_{1}$ & 0,107 & 0,015 & 0,139 & 7,23 & 0,015 \\
\hline & $\mathrm{X}_{1} \mathrm{X}_{2}$ & 0,013 & 0,004 & 0,751 & 3,42 & 0,026 \\
\hline & Adjusted $\left(\mathrm{R}^{2}\right)$ & & & 0,605 & & \\
\hline & F Arithmetic & & & 156,164 & & \\
\hline & Significance F & & & 0,000 & & \\
\hline
\end{tabular}

Source: Data Processed (2017)

Based on the above table can be seen Goodness of Fit from the regression analysis results with moderating variables as follows:

a) Regression Equation

The regression equation is obtained as follows.

$\mathrm{Y}=11,813+0,107 \mathrm{X} 1+0,013 \mathrm{X} 1 \mathrm{X} 2+\mathrm{e}$

b) Model Feasibility Test (F-Test)

Based on Table 2, it can be seen that the significance of $F$ is smaller than $\alpha(0,000<0.05)$. Therefore, it can be concluded that the model used in the study was feasible (Fit).

c) Hypothesis Test (t-test)

1. The influence of culture of THK on the use of AIS

Based on Table 2, it can be seen that the significance of variable $\mathrm{X}_{1}$ is smaller than $\alpha(0.015<0.05)$. Therefore, it can be concluded that culture of THK has a positive effect on the use of AIS. The result is obtained supporting the hypothesis has been made. The study results are in accordance with Suardikha (2011), and Suardikha (2013) studies found that culture of THK influences the use of AIS. THK is local wisdom that becomes a benchmark for individuals in Bali to carry out their activities within an organization, including in the use of AIS.

2. Moderation of ease of use perception to relationship between culture of THK and AIS usage

Based on Table 2, it can be seen that the significance of $\mathrm{X}_{1} \mathrm{X}_{2}$ interaction variable is smaller than $\alpha$ $(0.026<0.05)$. Therefore, it can be concluded that the ease of use perception strengthens to the relationship between the culture of THK and AIS usage. The result is obtained supporting the hypothesis has been made. If SMEs in Bali apply culture of THK to the use of AIS, the balance generated is implementation on the culture of THK will be more effective in using AIS, especially, if the user perceived ease when using AIS.

d) Coefficient of Determination $\left(\mathrm{R}^{2}\right)$

Based on Table 2, it can be seen that Adjusted $\left(\mathrm{R}^{2}\right)$ obtained is 0.605 . Therefore, it can be concluded that $60.5 \%$ variable of AIS usage can be explained by the culture of THK moderated by the ease of use perception. Whereas, the rest equal is $39.5 \%$ explained by other variables that are not presented in the research model.

\section{Conclusion}

Based on the research result at implementing of the culture of THK, ease of use perception, and the use of AIS at SMEs in Badung Regency can be drawn two conclusions. Those are:

a) The culture of THK has a positive effect on the use of AIS.

b) Ease of use perception strengthens towards the relationship between the culture of THK and the use of AIS. 
Suggestions for the further researcher to use other variables as moderators to further research can be more varied.

Conflict of interest statement and funding sources

The authors declared that they have no competing interest. The study was financed by personal funding.

Statement of authorship

The authors have a responsibility for the conception and design of the study. The authors have approved the final article.

\section{Acknowledgments}

Our deep and sincere gratitude were presented to God for having granted us the ability and the opportunity to complete this paper. As well as, we have much appreciated to our friends for their support, suggestion, contribution in finishing this research. We would like thanking I Wayan Suryasa that has given us a good advisement. Last but not least, we dedicated our dreadful thank my friend who those as editor in ScienceScholar, who has reviewed and approved this study to be published.

Dewi, I., Dewi, I., Kustina, K., \& Prena, G. (2018). Culture of tri hita karana on ease of use perception and use of accounting information system. International Journal Of Social Sciences And Humanities (IJSSH), 2(2), 77-86. doi:10.29332/ijssh.v2n2.131 


\section{References}

1. Aryani, N. L. (2018). Implementation of Communication Ethics in Building Social Harmony. International Journal of Social Sciences and Humanities (IJSSH), 2(1), 147-156.

View in (Google Scholar)

2. Bodnar, G. H., \& Hopwood, W. S. (2010). Accounting System Information. Boston: Person Education. View in (Google Scholar)

3. Burch, J., \& Grudnitski, G. (1989). Information systems: theory and practice. View in (Google Scholar)

4. Dalem, A. A. G. R. (2007). Implementasi Tri HitaKarana dalam bidang Pariwisata Menuju Pembangunan Berkelanjutan. Jurnal lingkungan Hidup Bumi Lestari PPLH-UNUD Denpasar, 7(1), 78-84.

View in (Google Scholar)

5. Davis, F. D. (1989). Perceived usefulness, perceived ease of use, and user acceptance of information technology. MIS quarterly, 319-340.

View in (Google Scholar)

6. Davis, F. D., Bagozzi, R. P., \& Warshaw, P. R. (1989). User acceptance of computer technology: a comparison of two theoretical models. Management science, 35(8), 982-1003.

View in (Google Scholar)

7. Ghozali, I. (2006). Aplikasi analisis multivariate dengan program SPSS. Badan Penerbit Universitas Diponegoro.

View in (Google Scholar)

8. Gunawan, A. (2014). Aplikasi Technology Acceptance Model Pada Minat Nasabah Untuk Menggunakan Internet Banking. Nominal, Barometer Riset Akuntansi dan Manajemen, 3(2).

View in (Google Scholar)

9. Halim, A. (1994). Bunga rampai Sistem Informasi Akuntansi. Edisi Pertama, BPFE, Yogyakarta.

View in (Google Scholar)

10. Hartono, J. (2007). Sistem Informasi Keperilakuan. ANDI: Yogyakarta.

View in (Google Scholar)

11. Kustina, K. T., Dewi, I. G. A. A. O., Prena, G. D., \& Utari, I. G. A. D. (2018). MSMEs Credit Distribution and NonPerforming Loan towards Banking Companies Profit in Indonesia. International Journal of Social Sciences and Humanities (IJSSH), 2(1), 10-23.

View in (Google Scholar)

12. Manurung, A. H. (2006). Bisnis UKM (Usaha Kecil Menengah).

View in (Google Scholar)

13. Mulyadi, D., \& Ak, M. S. (2001). Sistem Akuntansi. Edisi ketiga. Jakarta: Salemba Empat. View in (Google Scholar)

14. Nobes, C., Parker, R. B., \& Parker, R. H. (2008). Comparative international accounting. Pearson Education. View in (Google Scholar) 
15. Noviana, E. D., Suprijanto, A., \& Oemar, A. (2017). Pengaruh persepsi wajib pajak orang pribadi pada penerapan e-filling terhadap kepatuhan dalam menyampaikan spt tahunan di kpp kota semarang. Journal Of Accounting, 3(3).

View in (Google Scholar)

16. Novliadi, F. (2007). Intensi turnover karyawan ditinjau dari budaya perusahaan dan kepuasan kerja. Intensi Turnover Karyawan Ditinjau Dari Budaya Perusahaan Dan Kepuasan Kerja. View in (Google Scholar)

17. Suardikha, I. M. S. (2013). Pengaruh Budaya Tri Hita Karana Terhadap Penggunaan Sistem Informasi Akuntansi Dimediasi Persepsi Kegunaan Dan Persepsi Kemudahan Penggunaan. Jurnal Akuntansi dan Keuangan Indonesia, 10(1), 102-128.

View in (Google Scholar)

18. Suardikha, I. M. S., SUTRISNO, T., SUKOHARSONO, E. G., \& PURNOMOSIDHI, B. (2012). Pengaruh Implementasi Budaya Tri Hita Karana Terhadap Penggunaan Sistem Informasi Akuntansi dimediasi Keyakinan-diri atas Komputer, Keinovatifan Personal, Persepsi Kegunaan, dan Persepsi Kemudahan Penggunaan pada Bank Perkreditan Rakyat di Bali. Disertasi. Program Doktor Ilmu Akuntansi, Program Pascasarjana Falkultas Ekonomi dan Bisnis Universitas Brawijaya Malang.

View in (Google Scholar)

19. Suardikha, I. M. S., SUTRISNO, T., SUKOHARSONO, E. G., \& PURNOMOSIDHI, B. (2012). Pengaruh Implementasi Budaya Tri Hita Karana Terhadap Penggunaan Sistem Informasi Akuntansi dimediasi Keyakinan-diri atas Komputer, Keinovatifan Personal, Persepsi Kegunaan, dan Persepsi Kemudahan Penggunaan pada Bank Perkreditan Rakyat di Bali. Disertasi. Program Doktor Ilmu Akuntansi, Program Pascasarjana Falkultas Ekonomi dan Bisnis Universitas Brawijaya Malang.

View in (Google Scholar)

20. Tunnell, H. D. (2013, November). Combining technology acceptance and culture in one tool: Implications for information sharing within coalitions. In Military Communications Conference, MILCOM 2013-2013 IEEE (pp. 1125-1132). IEEE.

View in (Google Scholar)

21. Umar, H. (2000). Metodologi Penelitian. Gramedia Pustaka Umum, Jakarta.

View in (Google Scholar)

22. Wirawan, I. W. A. (2018). Maintaining Social Relationship of Balinese and Sasak Ethnic Community. International Journal of Social Sciences and Humanities (IJSSH), 2(1), 92-104.

View in (Google Scholar)

Dewi, I., Dewi, I., Kustina, K., \& Prena, G. (2018). Culture of tri hita karana on ease of use perception and use of accounting information system. International Journal Of Social Sciences And Humanities (IJSSH), 2(2), 77-86. doi:10.29332/ijssh.v2n2.131 


\section{Biography of Author}

\begin{tabular}{|l|l|}
\hline I Gusti Ayu Agung Omika Dewi, SE., MSA., AK., CA. is a senior lecturer at Undiknas \\
University. Her email address is omikadewi@undiknas.ac.id and a civil servant. She \\
is interested in accounting studies. She finished her Bachelor Degree in accounting \\
at Udayana University, Denpasar, Bali-Indonesia. She completed her Master Degree \\
at Brawijaya University, Malang-Indonesia in 2010. He had chartered accountant \\
No. 11. D40670 for CA degree from IAI (Indonesian Accountant Association) since \\
August 26 2 th 2014. She taught some subjects included corporate social \\
responsibility, contemporary financial accounting, introduction of accounting I \& II, \\
management information system, accounting information system.
\end{tabular}

